\title{
Local regulation of vasopressin and oxytocin secretion by extracellular ATP in the isolated posterior lobe of the rat hypophysis
}

\author{
B Sperlágh, Zs Mergl ${ }^{1}$, Zs Jurányi, E S Vizi and G B Makara ${ }^{1}$ \\ Department of Pharmacology, Institute of Experimental Medicine, Hungarian Academy of Sciences, H-1450 Budapest, PO Box 67, Hungary \\ ${ }^{1}$ Department of Neuroendocrinology, Institute of Experimental Medicine, Hungarian Academy of Sciences, H-1450 Budapest, PO Box 67, Hungary \\ (Requests for offprints should be addressed to E S Vizi)
}

\begin{abstract}
It is now widely accepted that ATP functions as a signalling substance in the nervous system. The presence of $\mathrm{P}_{2}$ receptors mediating the action of extracellular ATP in brain regions involved in hormonal regulation raises the possibility that a similar role for ATP might also exist in the neuroendocrine system. In this study, the release from the rat isolated neurohypophysis preparation of endogenous ATP, oxytocin and vasopressin (AVP) were measured simultaneously using luciferin-luciferase and RIA techniques. After $70 \mathrm{~min}$ preperfusion, electrical field stimulation caused a rapid increase in the amount of ATP in the effluent and the release of AVP and oxytocin also increased stimulation-dependently. Inhibition of voltage-dependent $\mathrm{Na}^{+}$channels by tetrodotoxin $(1 \mu \mathrm{M})$ reduced the stimulation-evoked release of AVP and oxytocin; however, the evoked release of ATP remained unaffected.

The effect of endogenous ATP on the hormone secretion was tested by suramin $(300 \mu \mathrm{M})$, the $\mathrm{P}_{2}$ receptor antagonist. Suramin significantly increased the release of
\end{abstract}

AVP, and the release of oxytocin was also enhanced. ATP, when applied to the superfusing medium, decreased the release of AVP, but not that of oxytocin, and its effect was prevented by suramin.

ATP $(60 \mathrm{nmol})$, added to the tissues, was readily decomposed to ADP, AMP and adenosine measured by HPLC combined with ultraviolet light detection, and the kinetic parameters of the enzymes responsible for inactivation of ATP (ectoATPase and ecto5'-nucleotidase) were also determined $\left(K_{\mathrm{m}}=264 \pm 2.7\right.$ and $334 \pm 165 \mu \mathrm{M}$ and $\mathrm{v}_{\max }=6.7 \pm 1.1$ and $2.54 \pm 0.24 \mathrm{nmol} / \mathrm{min}$ per preparation $(n=3)$ for ectoATPase and ecto5'-nucleotidase respectively).

Taken together, our data demonstrate the stimulationdependent release, $\mathrm{P}_{2}$ receptor-mediated action and extracellular metabolism of endogenous ATP in the posterior lobe of the hypophysis and indicate its role, as a paracrine regulator, in the local control of hormone secretion.

Journal of Endocrinology (1999) 160, 343-350

\section{Introduction}

Although the function of ATP as a ubiquitous extracellular signalling substance has been gaining an increasing body of experimental support for decades (Drury \& Szent-Györgyi 1929, cf. Burnstock 1997), it has only recently been recognized that it also acts as a neuroendocrine regulatory messenger (Chen et al. 1995b). Subtypes of the $\mathrm{P}_{2}$ purinoceptor superfamily mediating the action of extracellular ATP are widely distributed in neural and non-neuronal tissues, and they are also expressed in organs involved in endocrine regulation, including the pituitary (Brake et al. 1994, Chen et al. 1995b, North 1996). Until now, research interest in this field has concentrated on the anterior lobe of the pituitary gland, where both the exocytotic release of endogenous ATP (Chen et al. 1995a, Tomic et al. 1996) and its $\mathrm{P}_{2}$ purinoceptor-mediated effect on $\mathrm{Ca}^{2+}$ influx (Chen et al. 1995a) and on gonadotroph secretion (Chen et al. 1995a, Tomic et al. 1996) have been demonstrated. ATP is co-stored with neuropeptides in the secretory granules of neurohypophyseal nerve endings in millimolar concentrations (Gratzl et al. 1980) and cytochemical localization of ectoATPase enzyme, terminating the action of extracellular ATP (cf. Zimmermann 1996), has also been shown in the neurohypophysis (Thirion et al. 1996), which permits the hypothesis that a similar autocrine/paracrine role of ATP also exists in the posterior lobe of the hypophysis. However, crucial evidence, i.e. stimulationdependent ATP release and $\mathrm{P}_{2}$ purinoceptor-mediated action on hormone secretion, is missing in this respect.

There are reports showing that ATP receptors are involved in the brainstem-pituitary pathway regulating vasopressin (AVP) secretion (Day et al. 1993, Buller et al. 1996) and our previous study showed that ATP is coreleased with noradrenaline from nerve terminals of noradrenergic ascending bundle-innervating neurosecretory cells of the hypothalamus (Sperlágh et al. 1998b). In the present study we examined the possibility of whether ATP is released from the lower part of this pathway, downstream from the hypothalamus, i.e. from the posterior lobe 
of the pituitary; its inactivation by sequential hydrolysis by ectoATPase and ecto5'-nucleotidase was also studied. In addition, the regulatory influence of endogenous ATP via $\mathrm{P}_{2}$ purinoceptors was also demonstrated.

\section{Materials and Methods}

Male and female Wistar rats (Richter Gedeon, Budapest, Hungary) weighing 180-220 g were used. Animals were housed in groups of four or five and kept under constant indoor conditions $\left(20^{\circ} \mathrm{C}, 12 \mathrm{~h}\right.$ light $-12 \mathrm{~h}$ darkness cycles $)$ for at least 1 week before the experiments. They had free access to standard commercial pellets and drinking water. On the day of experiment, rats were killed by decapitation and brains were quickly removed. The neural and intermediate lobes of the pituitary gland were dissected from the anterior lobe under a stereomicroscope and immersed in ice-cold Krebs' solution (containing $(\mathrm{mM}): \mathrm{NaCl} 113$, $\mathrm{KCl} 4 \cdot 7, \mathrm{CaCl}_{2} 2 \cdot 5, \mathrm{KH}_{2} \mathrm{PO}_{4} 1 \cdot 2, \mathrm{MgSO}_{4} 1 \cdot 2, \mathrm{NaHCO}_{3}$ $25 \cdot 0$, glucose $11 \cdot 5$ ) bubbled with a mixture of $95 \% \mathrm{O}_{2}$ and $5 \% \mathrm{CO}_{2}$. The neural lobe was subsequently separated from intermediate lobe cells, as described earlier (Kárteszi et al. 1981) and four neurohypophyses were placed into one of four polypropylene $100 \mu \mathrm{l}$ superfusion chambers (Vizi et al. 1985) and perfused continuously with Krebs' solution preheated to $37^{\circ} \mathrm{C}$ and gassed with $95 \% \mathrm{O}_{2}$ and $5 \% \mathrm{CO}_{2}$. After a $70 \mathrm{~min}$ preperfusion period, perfusate samples were collected at $3 \mathrm{~min}$ intervals for the assay of ATP, AVP and oxytocin.

Electrical field stimulation was applied twice $\left(\mathrm{S}_{1}, \mathrm{~S}_{2}\right)$ through a pair of platinum ring electrodes at $30 \mathrm{~min}$ intervals by means of a Grass S88 stimulator (Quincy, MA, USA); square-wave pulses of $3 \mathrm{~ms}$ duration were delivered at $25 \mathrm{~V}, 10 \mathrm{~Hz}$ for $36 \mathrm{~s}$ (i.e. 360 shocks/stimulation period were applied). A similar stimulation paradigm has been used in previous studies to study stimulation-dependent release of ATP from different brain slice preparations (Cunha et al. 1996, Sperlágh et al. 1998a,b) in response to neural activity.

\section{Assay of ATP and ADP}

ATP released from the preparations was assayed using the luciferin-luciferase technique, as previously described (Sperlágh et al. 1995). Briefly, $100 \mu \mathrm{l}$ aliquots of the samples were added to $40 \mu \mathrm{l}$ of ATP assay mix (Sigma, St Louis, MO, USA) containing $0.33 \mathrm{mg}$ firefly luciferase, 0.83 mg luciferin, $6 \mathrm{mg} \mathrm{MgSO}_{4}, 2 \mathrm{mg}$ EDTA, 0.08 mg dithiothreitol, $5 \mathrm{mg}$ BSA and $45 \mathrm{mg}$ tricine, reconstituted in $5 \mathrm{ml}$ sterile water and the luminescence was measured in a BioOrbit 1250 luminometer (Turku, Finland) for $15 \mathrm{~s}$ and analysed with LUMINO 1250 software (Turku, Finland). Before the experiments a standard calibration curve was prepared from different concentrations of ATP ranging from $10^{-9}$ to $10^{-12} \mathrm{M}$, and a high correlation could be observed between light emission and ATP concentration $(r=0.997)$. The actual ATP levels in the samples were calculated by a double log curve fitting program and expressed in $\mathrm{pmol} / \mathrm{g}$ of tissue. The Krebs' solution with or without drugs was assayed for background ATP content. The increase in the release of ATP caused by electrical field stimulation $\left(\mathrm{S}_{1}, \mathrm{~S}_{2}\right)$ was calculated by subtracting the resting release measured during the prestimulation period from the release during the stimulation and after the stimulation period, and expressed in $\mathrm{pmol} / \mathrm{g}$. The effect of drugs on ATP release was expressed as the ratio of $S_{2}$ over $S_{1}$ in the presence and absence of the drug. Drugs were added to the perfusion fluid between $S_{1}$ and $\mathrm{S}_{2}, 18 \mathrm{~min}$ prior to $\mathrm{S}_{2}$, and were kept in the solution throughout the experiment.

\section{AVP and oxytocin assay}

AVP and oxytocin levels in the perfusate samples were determined by RIA as described earlier (Laczi et al. 1986, Vecsernyés et al. 1994) and expressed in $\mathrm{pmol} / \mathrm{mg}$ tissue.

\section{ATP metabolism studies}

Neurohypophyses were dissected from rats as described above, subdivided into three pieces and incubated in $3 \mathrm{ml}$ Krebs' solution at $37{ }^{\circ} \mathrm{C}$, bubbled with $95 \% \mathrm{O}_{2}$ and $5 \%$ $\mathrm{CO}_{2}$, and $60 \mathrm{nmol} \mathrm{ATP}$ added to the $3 \mathrm{ml}$ bath. Aliquots of $70 \mu \mathrm{l}$ were taken after $2 \cdot 5,5,10,15,20$ and $30 \mathrm{~min}$. The concentrations of AMP, ADP and ATP, after application of ATP, were measured by HPLC combined with ultraviolet light detection (HPLC-UV) according to the method described earlier (Sperlágh et al. 1995). The separation was carried out at room temperature with an analytical column $(15 \times 0.4 \mathrm{~cm})$ and a guard column $(2 \times 0.4 \mathrm{~cm})$ packed with Nucleosil C-18, particle size $3 \mu \mathrm{m}$ (Bio Separation Technology, Budapest, Hungary). The mobile phase was $50 \mathrm{mM}$ potassium phosphate with $1 \%(\mathrm{v} / \mathrm{v})$ methanol at $\mathrm{pH} 5 \cdot 5$. The flow rate was $0.5 \mathrm{ml} / \mathrm{min}$. Twenty microlitre aliquots of the samples were injected directly onto the column. The mobile phase was filtered through a $0.45 \mu \mathrm{m}$ type HA Millipore filter (Millipore, Bedford, MA, USA) and degassed before use. Peaks corresponding to ATP, ADP, AMP and adenosine were monitored by UV detection at $250 \mathrm{~nm}$ with a Model C-R6 A integrator (Shimadzu, Tokyo, Japan). The nucleotides were quantified with the standard addition methods from the peak area in the chromatogram. A linear correlation between the peak area and the injected amount was observed for all the nucleotides. The actual concentrations of ATP, ADP and AMP were expressed as $\mu \mathrm{M}$.

For the determination of the kinetic parameters of ectoATPase and ecto5'-nucleotidase, a linear regression for ATP or AMP concentrations as a function of time was calculated from the concentrations of the first five samples $(0,2 \cdot 5,5,10$ and 15) after three different initial 
concentrations of ATP or AMP $(20,100$ and $500 \mu \mathrm{M})$ and the slope was used as initial velocity $\left(\mathrm{v}_{\mathrm{i}}\right)$. The $\mathrm{v}_{\mathrm{i}}$ values were used for calculation of the parameters from the Lineweaver-Burk plot using linear line regression:

$$
1 / \mathrm{v}_{\mathrm{i}}=K_{\mathrm{m}} / \mathrm{v}_{\max } \times[\mathrm{S}]+1 / \mathrm{v}_{\max }
$$

where $\mathrm{v}_{\mathrm{i}}$ is the velocity measured when very little substrate has reacted, $[\mathrm{S}]$ is the concentration of the substrate, $\mathrm{v}_{\max }$ (maximal velocity) is a point where the enzyme is saturated with the substrate and $K_{\mathrm{m}}$ (Michaelis constant) is the concentration that produces half-maximal velocity.

\section{Materials}

The following chemicals were used: ATP assay mix, ATP, ADP, AMP, tetrodotoxin (TTX) (all from Sigma) and suramin hexasodium (Bayer, Leverkeusen, Germany).

\section{Statistics}

The results were evaluated by one-way ANOVA followed by Dunnett's test (multiple comparisons), or Student's $t$-test or Welch test (pairwise comparisons). $P$ values of less than 0.05 were considered statistically significant. All data were expressed as means \pm s.E.M.

\section{Results}

Stimulation-dependent release of endogenous ATP, AVP and oxytocin from the isolated posterior lobe of the hypophysis

After a $70 \mathrm{~min}$ preperfusion period, the basal release of ATP was measured by the luciferin-luciferase assay $(85 \cdot 08 \pm 7 \cdot 18 \mathrm{pmol} / \mathrm{g}$ tissue in $3 \mathrm{~min}, n=6)$ and remained constant during the subsequent sample collection period (Fig. 1A). The basal release of AVP and oxytocin was $60 \cdot 88 \pm 21 \cdot 82(n=6)$ and $106 \cdot 9 \pm 31 \cdot 02 \mathrm{pg} / \mathrm{mg} \quad(n=6)$ respectively. Electrical field stimulation $(10 \mathrm{~Hz}, 2.5 \mathrm{~ms}$, 360 shocks) increased the release of ATP to the superfusate, yielding $234.9 \pm 30.49 \mathrm{pmol} / \mathrm{g}$ evoked release $(n=6)$. The amount of ATP released by the subsequent stimulation period was less, resulting in an $\mathrm{S}_{2} / \mathrm{S}_{1}$ ratio of $0.54 \pm 0.06(n=6)$. The release of AVP and oxytocin was also substantially increased in response to electrical stimulation (Fig. 1B and C); the evoked release of AVP and oxytocin was $2404 \pm 313$ and $6865 \pm 917 \mathrm{pg} / \mathrm{mg}$ tissue $(n=6)$ respectively. After $30 \mathrm{~min}$, the second stimulation released less AVP and oxytocin, resulting in $\mathrm{S}_{2} / \mathrm{S}_{1}$ ratios of $0.69 \pm 0.07$ and $0.42 \pm 0.09(n=8)$ respectively.

Figure 1 shows that the onset and the fade of the stimulation-evoked outflows of ATP and posterior lobe hormones were not entirely identical. The response of ATP to stimulation was rapid, its peak appeared promptly in the sample collected during stimulation and faded in the next 3 min sample, while the outflows of AVP and oxytocin were longer-lasting, reaching their peaks $6 \mathrm{~min}$ after stimulation and declining in the next $18 \mathrm{~min}$. Furthermore, inhibition of the voltage-dependent $\mathrm{Na}^{+}$ channels by TTX $(1 \mu \mathrm{M})$ almost completely abolished the evoked release of AVP and oxytocin, while the release of ATP remained unaffected (Fig. 2), showing that the hormone release, but not ATP release in response to stimulation, is correlated with action potential propagation along the neuronal membrane.

\section{Effect of $\mathrm{P}_{2}$ receptor activation on hormone secretion}

The ability of endogenous ATP to affect the secretion of AVP and oxytocin in the neural lobe of the hypophysis was assessed by the use of suramin, a specific antagonist of $\mathrm{P}_{2}$ type purinoceptors (Fig. 3). Suramin $(300 \mu M)$ applied to the superfusion fluid $15 \mathrm{~min}$ prior to the second stimulation significantly increased the amount of oxytocin and AVP released by stimulation, suggesting that the tonic action of endogenous ATP decreases the release of AVP and oxytocin, an effect mediated by $\mathrm{P}_{2}$ purinoceptors. ATP ( $1 \mathrm{mM})$, by itself, diminished the release of AVP but not that of oxytocin (Fig. 3), and its effect was reversed by suramin $(300 \mu \mathrm{M})$; the $\mathrm{S}_{2} / \mathrm{S}_{1}$ ratios were $0.36 \pm 0.04$ and $1 \cdot 43 \pm 0.31$ in the presence of ATP and ATP plus suramin respectively $(n=5, P<0 \cdot 05)$.

\section{ATP metabolism studies}

The hydrolysis rates of $60 \mathrm{nmol}$ ATP and AMP added to $3 \mathrm{ml}$ incubation medium were also measured in the preparations by the HPLC-UV technique, by assaying ATP, ADP and AMP concentrations in the bathing fluid after drug administration (Fig. 4). ATP was readily decomposed by the enzymatic action of ectoATPase; conversely, the amount of ADP and AMP was increased (Fig. 4A). Similarly, when $60 \mathrm{nmol}$ AMP were added to the tissues, its amount declined, and adenosine appeared in the extracellular fluid (Fig. 4B), showing the activity of ecto5'-nucleotidase enzyme. The kinetic parameters of the ectoATPase and ecto5'-nucleotidase were determined by initial rate measurements (Sperlágh et al. 1995); the $K_{\mathrm{m}}$ and $\mathrm{v}_{\max }$ values of ectoATPase were $267 \pm 52.68 \mu \mathrm{M}$ and $6.70 \pm 1.08 \mathrm{nmol} / \mathrm{min}$ per preparation $(n=3)$ respectively, and $334 \pm 165 \mu \mathrm{M}$ and $2.54 \pm 0.24 \mathrm{nmol} / \mathrm{min}$ per preparation $(n=3)$ respectively for ecto $5^{\prime}$-nucleotidase.

\section{Discussion}

Neurohypophyseal regulation is conveyed on different levels; oxytocin and AVP secretion from the terminals of magnocellular neurons of the supraoptic nucleus is controlled by factors circulating in the blood and neuronal factors acting on the cell body in the hypothalamus. In 

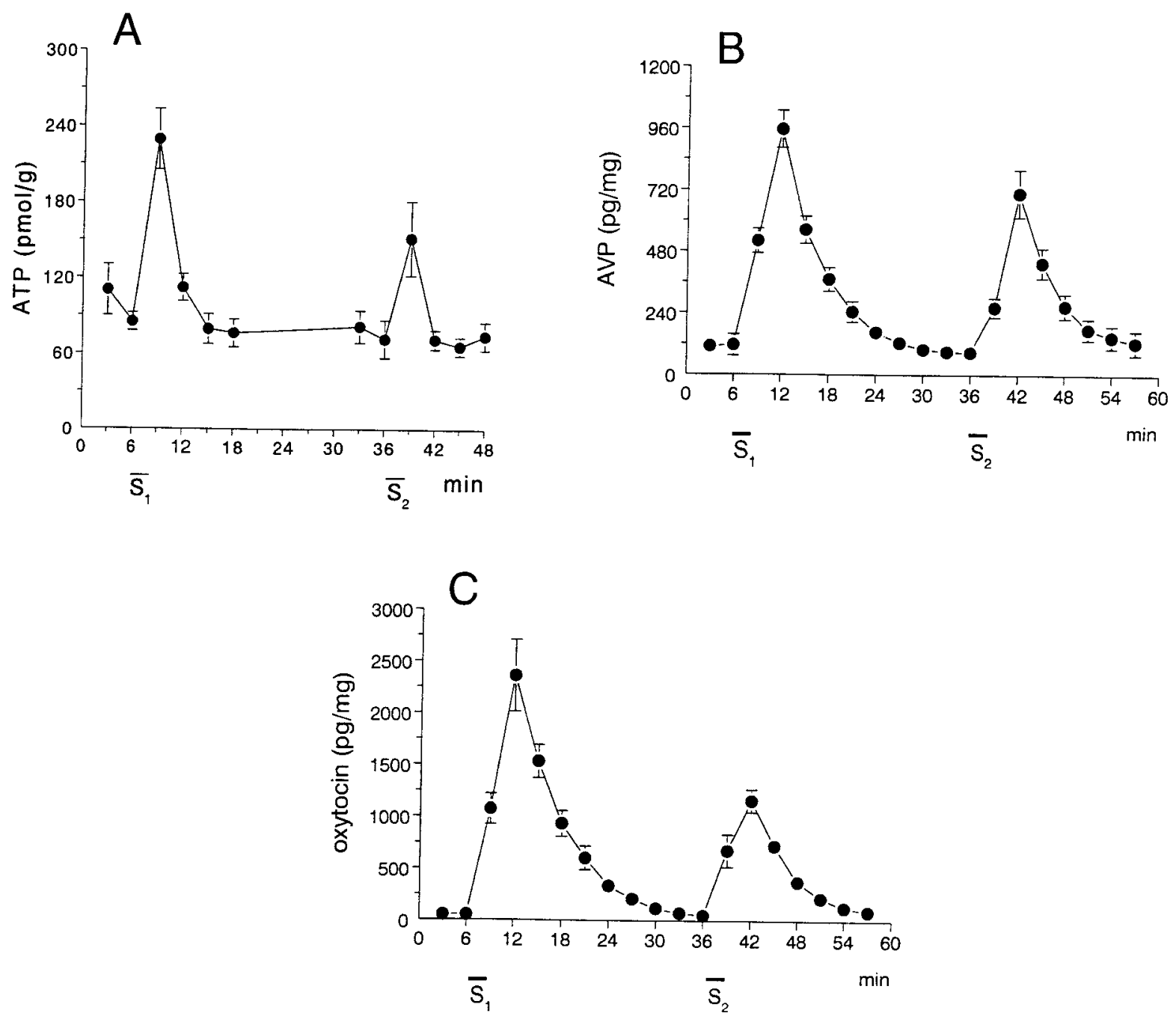

Figure 1 Electrical field stimulation-induced release of ATP (A), AVP (B) and oxytocin (C) from the isolated posterior pituitary preparation. Tissues were superfused with Krebs' solution for 70 min, stimulated electrically twice $\left(\mathrm{S}_{1}, \mathrm{~S}_{2}, 10 \mathrm{~Hz}, 3 \mathrm{~ms}, 360\right.$ shocks $)$ and perfusate samples collected. ATP levels in the samples were measured by the luciferin-luciferase assay, AVP and oxytocin by RIA. The release of ATP was expressed in $\mathrm{pmol} / \mathrm{g}$, that of AVP and oxytocin in $\mathrm{pg} / \mathrm{mg}$, as a function of time. Data are means \pm S.E.M of eight identical experiments.

addition, regulation at the terminal level by autocrine/ paracrine mediators via a non-synaptic mechanism (Vizi \& Lábos 1991) also appears to be important.

The question addressed in this study was whether purinergic signalling mechanisms might operate at the terminal level of this regulatory cascade, i.e. in the isolated posterior lobe of the hypophysis. If a compound acts as an intercellular signal the following conditions have to be fulfilled: (i) it has to be released into the extracellular milieu in response to a physiological activation signal; (ii) it has to be removed from the extracellular space by an inactivation system; and (iii) it has to affect the function of the target cells via specific receptor-mediated mechanisms.
In our experiments, the release of endogenous ATP, measured by the luciferin-luciferase assay, and of AVP and oxytocin were simultaneously detected from the same preparations. Electrical field stimulation at $10 \mathrm{~Hz}$, which is close to the physiological firing patterns of AVP neurons (average frequency of $12-13 \mathrm{~Hz}$, Bondy et al. 1988), elicited a rapid release of ATP, reaching a more than twofold increase above the background ATP level. AVP and oxytocin were also released in a remarkable amount in response to stimulation; nevertheless, the time courses of the release of ATP and hormone secretion were not identical. The peak of the ATP release appeared promptly after the stimulation period, and the response returned to 


\section{Control $\square$ TTX, $1 \mu \mathrm{M}$}

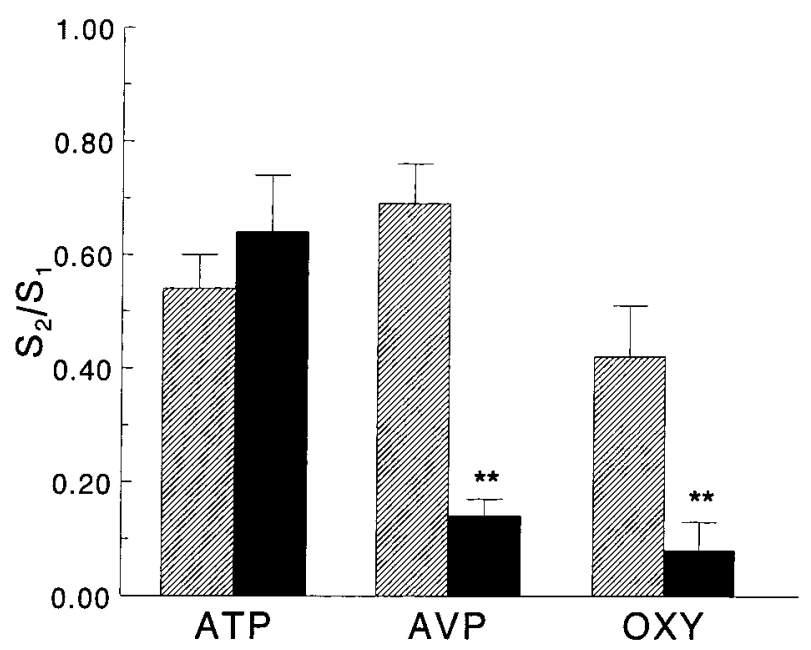

Figure 2 Effect of TTX $(1 \mu \mathrm{M})$ on the evoked release of ATP, AVP and oxytocin. TTX was administered into the perfusion fluid 18 min prior to the second stimulation period $\left(\mathrm{S}_{2}\right)$. Its effect on the stimulation-evoked release of ATP, AVP and oxytocin (OXY) was expressed as $S_{2} / S_{1}$ ratios. Asterisks represent significant differences between control groups and TTX-treated groups $\left({ }^{* *} P<0 \cdot 01, n=5\right)$. the baseline in the next 3 min period. Conversely, the secretions of oxytocin and AVP were delayed, reaching their peak $6 \mathrm{~min}$ after stimulation and lasted for $18 \mathrm{~min}$. Evidently different ATP and hormone release profiles may be explained by the fact that the posterior lobe preparation is $0 \cdot 5-1 \mathrm{~mm}$ thick and different compounds will take different times to diffuse from within the tissue to the perfusion fluid. As indicated by ATP breakdown experiments (see Fig. 4), ATP is rapidly metabolized in the extracellular space by ectonucleotidases, and a part of the released ATP is probably hydrolysed before diffusion to the perfusate, resulting in a short-lasting response. Presumably, AVP and oxytocin have longer extracellular half-lives and their outflows were more prolonged than the outflow of ATP. The question arises: what is the cellular and subcellular origin of released ATP, and is it identical with that of posterior pituitary hormones?

While AVP and oxytocin are derived from the neurosecretory nerve terminals of the neurohypophysis, there are three potential source of extracellular ATP: (i) afferent nerve terminals terminating in the neurohypophysis; (ii) pituicytes, specified glial cells of the posterior lobe; and (iii) neurosecretory nerve endings. As ATP is present in the neurosecretory granules (Gratzl et al. 1980), the origin of the released ATP should, at least partly, be a common or separate pool of the granules. However, abolition of axon
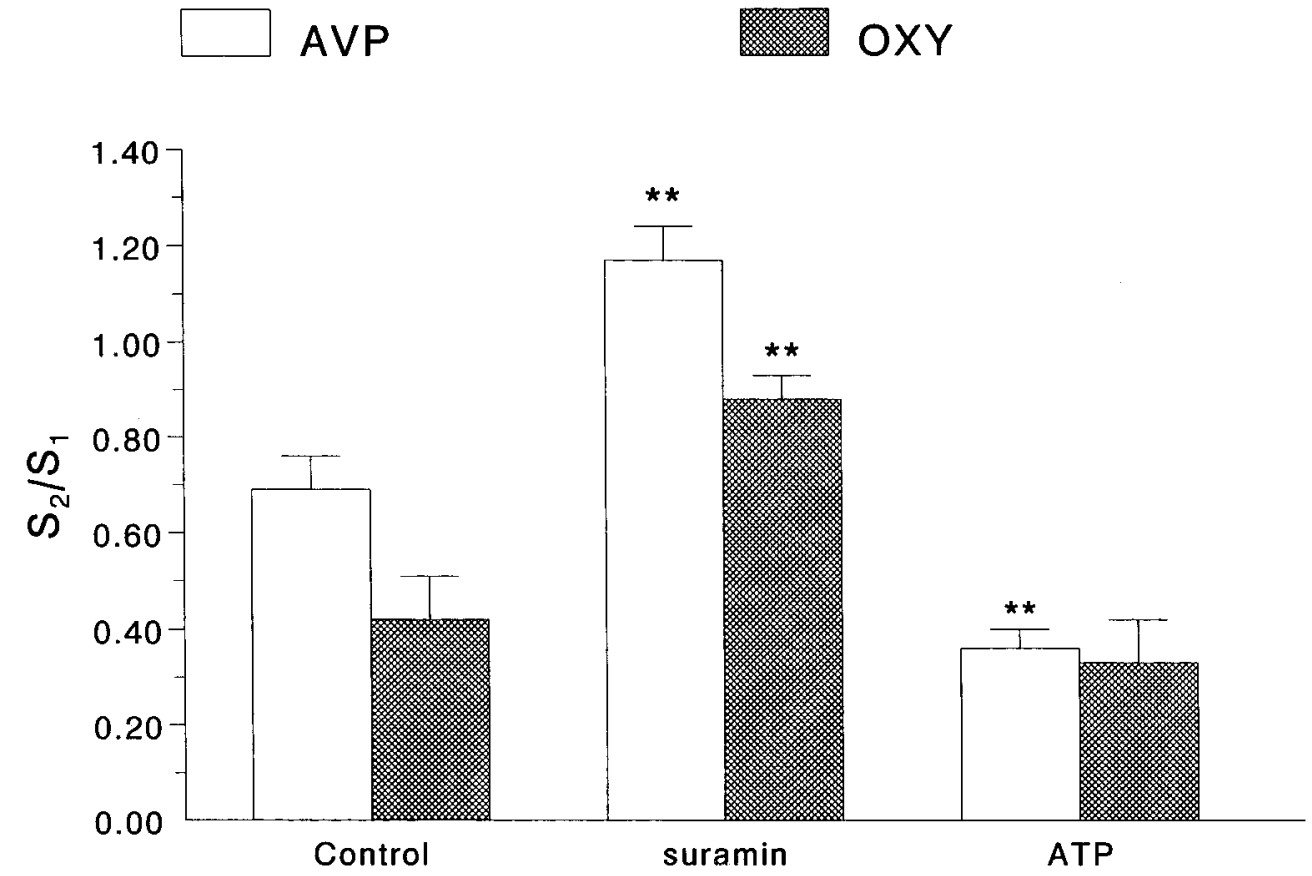

Figure 3 Effect of suramin and ATP on the evoked release of AVP and oxytocin (OXY). Suramin and ATP were administered into the perfusion fluid $18 \mathrm{~min}$ prior to the second stimulation period $\left(\mathrm{S}_{2}\right)$. Their effect on the stimulation-evoked release of AVP and oxytocin was expressed as $S_{2} / S_{1}$ ratios. Asterisks represent significant differences between control groups and drug-treated groups $(* * P<0 \cdot 01, n=4-6)$. 

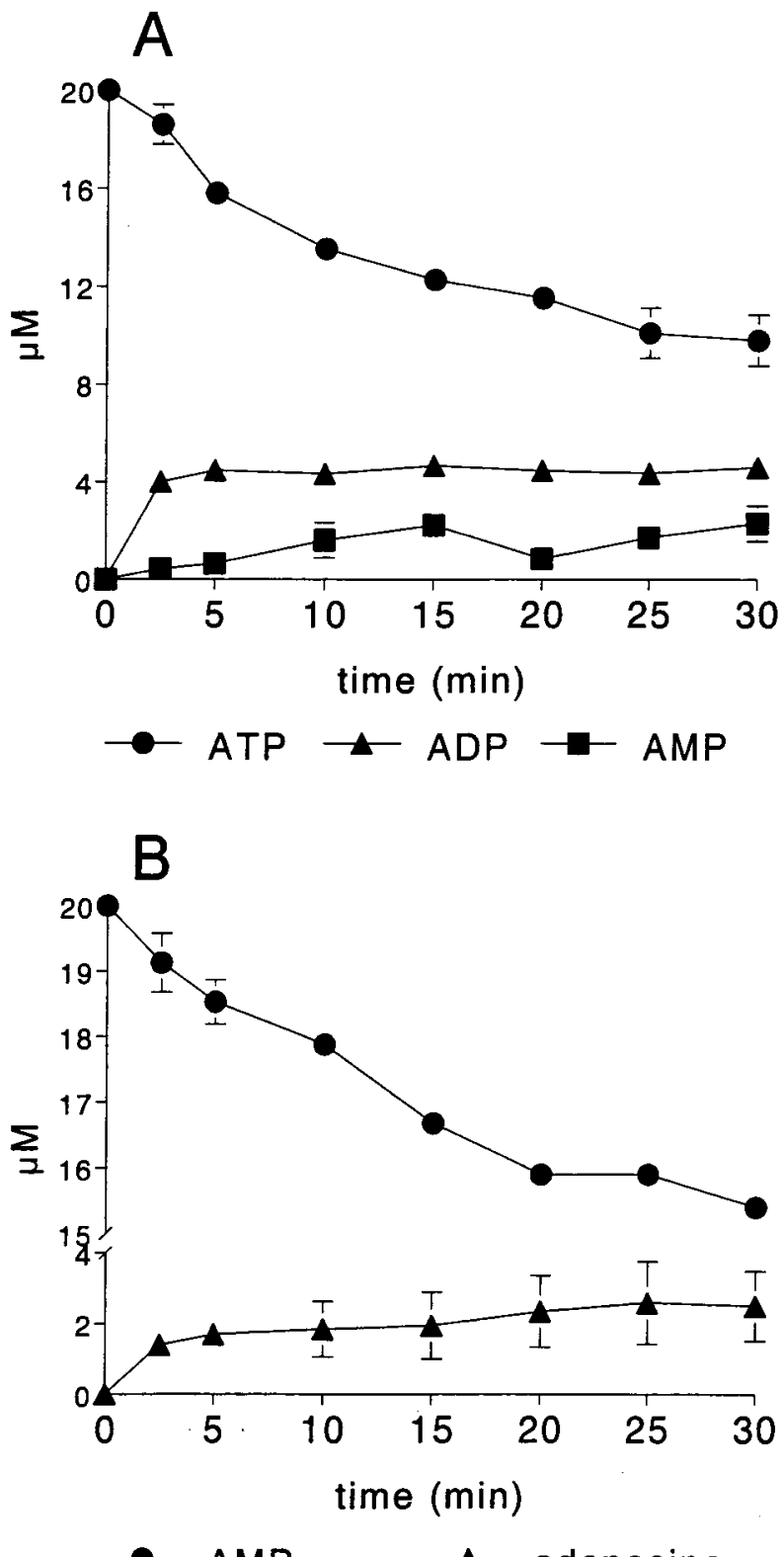

Figure 4 EctoATPase (A) and ecto5'-nucleotidase (B) activity in the isolated posterior pituitary preparation. Preparations were incubated in $3 \mathrm{ml} \mathrm{Krebs}$ solution in the presence of $60 \mathrm{nmol}$ ATP. Aliquots $(70 \mu \mathrm{l})$ were taken $2 \cdot 5,5,10,15,20,25$ and $30 \mathrm{~min}$ after the addition of ATP. The amounts of nucleotides and adenosine in the aliquots were determined by the HPLC-UV method and expressed as $\mu \mathrm{M}$. Data are the means \pm S.E.M. of three identical experiments.

potential propagation by TTX strongly reduced hormone secretion, while the release of ATP remained unaffected, which indicates that the majority of ATP and posterior lobe hormones represented in the outflow have separate origins. The earlier and sharper peak of the release of ATP also suggests that the source of ATP is not identical to that of AVP and oxytocin. However, one also has to consider the fast extracellular hydrolysis of ATP (see Fig. 4), which prevents the capture of the total amount of released ATP. As for the TTX-resistant part of the release, its cellular source might be either the afferent nerve terminals or the pituicytes. In the lack of axonal conduction, i.e. in the presence of TTX, membranes can be stimulated directly by the applied electrical current. Depolarization-induced release of transmitters by electrical stimulation has been described from glial cells (Dennis \& Miledi 1974), and a similar, stimulation-dependent, TTX-resistant release of endogenous ATP was observed in the capsula glomerulosa preparation of the adrenal gland where steroid hormone secretion is regulated by $\mathrm{P}_{2}$ receptors (Jurányi et al. 1997). Boersma et al. (1993) observed synaptoid contacts between pituicytes and oxytocin- and AVP-containing axon terminals in the rat neural lobe, which provides an ultrastructural correlate for a local release of ATP from pituicytes in response to nerve terminal depolarization. Nevertheless, further studies are necessary to identify the exact source of released ATP. Another intriguing question is how the release of ATP is altered during other physiological stimuli regulating AVP and oxytocin secretion, such as osmotic stimulation, dehydration or stress.

The question arises: what is the functional consequence of local ATP release in the neurohypophysis? It is well known that oxytocin and AVP release are subject to modulation by a number of different receptors, including dopamine (Vizi \& Volbekas 1980), א-opioid (Leng et al. 1994), neuropeptide $Y$ (Larsen et al. 1994) and $\gamma$ aminobutyric acid-A (GABA-A) (Magnusson \& Meyerson 1993) receptors, and by nitric oxide (Lutz-Bucher \& Koch 1994 , Pow 1994) at the pituitary level. The $\mathrm{P}_{2}$ purinoceptor family is a growing receptor family, which is divided into the ionotropic $\left(\mathrm{P}_{2 \mathrm{x}}\right)$ and metabotropic $\left(\mathrm{P}_{2 \mathrm{y}}\right)$ receptor subfamilies; seven members of each subfamily have been molecularly identified so far (Buell et al. 1996). Since $\mathrm{P}_{2 \mathrm{x}}$ receptors are present in the pituitary (Brake et al. 1994, Chen et al. 1995b, North 1995) and $\mathrm{Ca}^{2+}$ currents in isolated neurohypophyseal nerve terminals have been shown to be modulated by ATP (Wang \& Lemos 1993, Troadec et al. 1998), it appears a reasonable idea that hormone secretion is under the regulatory influence of ATP, via $\mathrm{P}_{2}$ receptors. In this study, suramin, the specific $\mathrm{P}_{2}$ receptor antagonist, was used to test this possibility, i.e. to displace the action of endogenous ligand on $\mathrm{P}_{2}$ receptors. Suramin, which possesses extended selectivity and acts on a wide array of both $\mathrm{P}_{2 \mathrm{x}}$ and $\mathrm{P}_{2 \mathrm{y}}$ subtypes (Burnstock 1997), increased the release of both oxytocin and AVP at a concentration at which it exhibits a $\mathrm{P}_{2}$ receptor antagonist property $(300 \mu \mathrm{M}$, Dunn \& Blakeley 1988), indicating that hormone secretion is under the inhibitory influence of ATP released in situ by nerve stimulation. However, recent studies indicated that suramin does not block exclusively $\mathrm{P}_{2}$ purinoceptors; it 
also inhibits glutamate and GABA receptor-mediated currents (Nakazawa et al. 1995), as well as the coupling of receptors to $G$ proteins (Beindl et al. 1996). Since the posterior lobe receives a well-defined GABAergic innervation from central nuclei (Oertel et al. 1982, Vincent et al. 1982, Buijs et al. 1987) and AVP release in the pituitary is modulated by GABA-A receptors (Anderson \& Mitchell 1986, Sladek \& Armstrong 1987, Magnuson \& Meyerson 1993), augmentation of oxytocin and AVP release by suramin could be explained by the removal of GABAergic regulatory influence. Glutamate immunoreactivity (Meeker et al. 1991) and metabotropic glutamate receptor subtypes (Kiyama et al. 1993) are also present in neurosecretory nerve terminals, as well as in pituicytes, and therefore glutamatergic modulation of hormone secretion has also to be considered. However, the finding that ATP reduced the release of AVP, and suramin prevented the inhibitory effect of ATP on hormone secretion, favours the assumption that the action of suramin is related to $\mathrm{P}_{2}$ purinoceptors and the efflux of at least AVP is regulated by endogenous ATP. Although a high concentration of ATP $(1 \mathrm{mM})$ was needed to obtain a significant effect, taking into account the rapid hydrolysis of ATP in the extracellular space, the concentration of ATP at the receptor site was probably much lower. Furthermore, the probability that ATP, added exogenously, competes for receptor sites with endogenously released ATP (see Figs 1A and 3), offers a further explanation for the relatively weak effect of exogenous ATP on hormone secretion.

In the third part of the study, the extracellular breakdown of ATP was examined using the HPLC-UV technique. When 60 nmol ATP was added to the tissues, it was readily hydrolysed to ADP and AMP, showing the activity of ectoATPase, an enzyme which is widely but not unevenly distributed in neural and non-neuronal tissues (Zimmermann 1996). These observations are consistent with the enzyme cytochemical findings of Thirion et al. (1995), who found that ectoATPase precipitates are abundantly localized around neurosecretory nerve terminals and pituicytes in the neurohypophysis. The $K_{\mathrm{m}}$ value of ectoATPase was in the high micromolar range, which indicates that its activity is high enough to metabolize the ATP amounts released upon depolarization. Therefore, in view of the fast extracellular hydrolysis of released ATP, the biophase concentration of ATP at release sites is probably higher than we detected in the release experiments. Furthermore, in our experiments, the activity of ecto5'-nucleotidase enzyme, which is responsible for the hydrolysis of AMP to adenosine, was also shown. These findings indicate that ATP is sequentially metabolized in the extracellular matrix to ADP, by ectoATPase, and to AMP and adenosine by the ecto5' ${ }^{\prime}$-nucleotidase, and the end-product of this inactivation process is adenosine. Since adenosine is a well-known neuromodulator, which is inactive on ATP receptors, but is active on adenosine receptors (cf. Windscheif 1996), our findings invite further investigation on possible adenosine receptor-mediated actions in the posterior pituitary. Otherwise, adenosine, accumulating in the extracellular fluid, is able to pass through the membrane by nucleoside transporters and is available for the resynthesis of ATP inside the cell.

In summary, our results clearly demonstrate that endogenous ATP is released stimulation-dependently and metabolized extracellularly in the rat isolated posterior pituitary. In addition, AVP secretion has been shown to be modulated by endogenous and exogenous ATP via $\mathrm{P}_{2}$ receptors, supporting the idea that ATP acts as an intercellular messenger in the neural lobe of the hypophysis.

\section{Acknowledgements}

This study was supported by the grants of the Hungarian Research Foundation (OTKA T025614, T016756, T016827) and Hungarian Medical Research Council (ETT 197/1996). The authors are grateful to Ms Éva Szénássy for excellent technical assistance and to Ms Klára Varga for RIA measurements.

\section{References}

Anderson RA \& Mitchell R 1986 Distribution of GABA binding site subtypes in rat pituitary gland. Brain Research 365 78-84.

Beindl W, Mitterauer T, Hohenegger M, Ijzerman AP, Nanoff C \& Freissmuth M 1996 Inhibition of receptor/G protein coupling by suramin analogues. Molecular Pharmacology 50 415-423.

Bondy CA, Gainer H \& Russell JT 1988 Dynorphyn A inhibits and naloxone increases the electrically stimulated release of oxytocin but not vasopressin from the terminals of the neural lobe. Endocrinology 122 1321-1327.

Brake AJ, Wagenbach MJ \& Julius D 1994 New structural motif for ligand gated ion channels defined by an ionotropic ATP receptor. Nature 371 519-523.

Boersma CJ, Sonnemans MA \& Van Leeuwen 1993 Immunoelectron microscopic demonstration of oxytocin and vasopresin in pituicytes and in nerve terminals forming synaptoid contacts with pituicytes in the rat neural lobe. Brain Research 611 117-129.

Buell G, Collo G \& Rassendren F $1996 \mathrm{P}_{2 \mathrm{x}}$ receptors: an emerging channel family. European Journal of Neuroscience 8 2221-2228.

Buijs RM, van Vulpen EHS \& Geffard M 1987 Ultrastructural localization of GABA in the supraoptic nucleus and neural lobe. Neuroscience 1 347-355.

Buller KM, Khanna S, Sibbald JR \& Day TA 1996 Central noradrenergic neurons signal via ATP to elicit vasopressin responses to haemorrhage. Neuroscience 73 637-642.

Burnstock G 1997 The past, present and future of purine nucleotides as signalling molecules. Neuropharmacology 36 1127-1141.

Chen Z, Kratzmeier M, Levy A, McArdle CA, Poch A, Day A, Mukhopadhyay AK \& Lightman SL 1995a Evidence for a role of pituitary ATP receptors in the regulation of pituitary function. Proceedings of the National Academy of Sciences of the USA 92 5219-5223.

Chen ZP, Levy A \& Lightman SL $1995 b$ Nucleotides as extracellular signalling molecules. Journal of Neuroendorinology 7 83-96.

Cunha RA, Vizi ES, Ribeiro JA \& Sebastiao AM 1996 Preferential release of ATP and its extracellular catabolism as a source of adenosine upon high- but not low-frequency stimulation of rat hippocampal slices. Journal of Neurochemistry 67 2180-2187. 
Day TA, Sibbald JR \& Khanna S 1993 ATP mediates an excitatory noradrenergic neuron input to supraoptic vasopressin cells. Brain Research 607 341-344.

Dennis MJ \& Miledi R 1974 Electrically induced release of acetylcholine from denervated Schwann cells. Journal of Physiology 237 431-452.

Drury AN \& Szent-Györgyi A 1929 The physiological activity of adenine compounds with special reference to their actions upon the mammalian heart. Journal of Physiology 68 213-237.

Dunn PM \& Blakeley AGH 1988 Suramin: a reversible P2 receptor antagonist in mouse vas deferens. British Journal of Pharmacology 93 243-245.

Gratzl M, Torp-Pedersen C, Daett DA, Treiman M \& Thorn NA 1980 Isolation and characterization of secretory granules from bovine neurohypophyses. Hoppe Seyler's Zeitschrift für Physiologische Chemie 361P 1615.

Jurányi Z, Orsó E, Jánossy A, Szalay K Sz, Sperlágh B, Windisch K, Vinson GP \& Vizi ES 1997 ATP and $\left[{ }^{3} \mathrm{H}\right]$ noradrenaline release and the presence of ectoATPases in the capsule-glomerulosa fraction of the rat adrenal gland. Journal of Endocrinology 153 105-114.

Kárteszi M, Stark E, Rappay Gy, László FA \& Makara GB 1981 Corticoliberin activity of rat neurohypophysis is distinct from vasopressin. American Journal of Physiology 240 E689-E693.

Kiyama H, Sato K \& Toyama M 1993 Characteristic localization of non-NMDA type glutamate receptor subunits in rat pituitary gland. Molecular Brain Research 19 262-268.

Laczi F, Iványi T, Julesz J, Janáky T \& László FA 1986 Plasma arginine-8-vasopressin responses to osmotic or histamine stimulation contribute to the differential diagnosis of central diabetes insipidus. Acta Endocrinologica 113 168-174.

Larsen PJ, Jukes KE, Chowdrey HS, Lightman SL \& Jessop DS 1994 Neuropeptide Y potentiates the secretion of vasopressin from the neurointermediate lobe of the rat pituitary gland. Endocrinology 134 $1635-1639$.

Leng G, Bicknell RJ, Brown D, Bowden C, Chapman C \& Russell JA 1994 Stimulus-induced depletion of pro-enkephalins, oxytocin and vasopressin and pro-enkephalin interaction with posterior pituitary hormone release in vitro. Neuroendocrinology 60 559-566.

Lutz-Bucher B \& Koch B 1994 Evidence for an inhibitory effect of nitric oxide on neuropeptide secretion from isolated neural lobe of the rat pituitary gland. Neuroscience Letters 165 48-50.

Magnusson AM \& Meyerson BJ 1993 GABA-A agonist muscimol inhibits stimulated vasopressin release in the posterior pituitary of Sprague-Dawley, Wistar, Wistar-Kyoto and spontaneously hypertensive rats. Neuroendocrinology 58 519-524.

Meeker RB, Swanson DJ, Greenwood RS \& Hayward JN 1991 Ultrastructural distribution of glutamate immunoreactivity within neurosecretory endings and pituicytes of the rat neurohypophysis. Brain Research 564 181-193.

Nakazawa K, Inoue K, Ito K, Koizumi S \& Inoue K 1995 Inhibition by suramin and reactive blue 2 of GABA and glutamate receptor channels in rat hippocampal neurones. Naunyn-Schmiedeberg's Archives of Pharmacology 351 202-208.

North RA $1996 \mathrm{P}_{2 \mathrm{x}}$ purinoceptor plethora. Seminars in the Neurosciences 8 187-195.

Oertel WH, Muignani E, Tappaz ML, Weise VK, Dahl A, Schmechel DE \& Kopin IJ 1982 Central GABAergic innervation if neurointermediate pituitary lobe: Biochemical and immunochemical study in the rat. Proceedings of the National Academy of Sciences of the USA 79 675-679.

Pow DV 1994 Immunocytochemical evidence for a glial localisation of arginine, and a neuronal localisation of citrulline in the rat neurohypophysis: implications for nitrergic transmission. Neuroscience Letters 181 141-144.

Sladek CD \& Armstrong WE $1987 \gamma$-Aminobutyric acid antagonists stimulate vasopressin release from organ cultured hypothalamoneurohypophyseal explants. Endocrinology 120 1576-1580.

Sperlágh B, Kittel Á, Lajtha A \& Vizi ES 1995 ATP acts as fast neurotransmitter in rat habenula: neurochemical and enzyme cytochemical evidence. Neuroscience 66 915-920.

Sperlágh B, Maglóczky Zs, Vizi ES \& Freund TF 1998a The triangular septal nucleus as the major source of ATP release in the rat habenula: a combined neurochemical and morphological study. Neuroscience 86 1195-1207.

Sperlágh B, Sershen H, Lajtha A \& Vizi ES 1998 b Co-release of endogenous ATP and $\left[{ }^{3} \mathrm{H}\right]$ noradrenaline from rat hypothalamic slices: origin and modulation by $\alpha_{2}$-adrenoceptors. Neuroscience $\mathbf{8 2}$ 511-520.

Thirion S, Troadec J-D \& Nicaise G 1996 Cytochemical localization of ectoATPases in rat neurohypophysis. Journal of Histochemistry and Cytochemistry 44 103-111.

Tomic M, Jobin RM, Vergara LA \& Stojilkovic SS 1996 Expression of purinergic receptor channels and their role in calcium signaling and hormone release in pituitary gonadotrophs. Journal of Biological Chemistry 271 21200-21208.

Troadec JD, Thirion S, Nicaise G, Lemos JR \& Dayanithi G 1998 ATP-evoked increases in $\left[\mathrm{Ca}^{2+}\right]_{i}$ and peptide release from rat isolated neurohypophyseal terminals via $\mathrm{P}_{2 \times 2}$ purinoceptor. Journal of Physiology 511 89-103.

Vecsernyés M, Torok A, Jójárt I, Laczi F, Penke B \& Julesz J 1994 Specific radioimmunoassay of oxytocin in plasma. Endocrine Regulations 28 145-150.

Vincent SR, Hökfelt T \& Wu J-Y 1982 GABA neuron systems in hypothalamus and the pituitary gland. Neuroendocrinology 34 $117-125$.

Vizi ES \& Lábos E 1991 Nonsynaptic interactions at presynaptic level. Progress in Neurobiology 37 145-163.

Vizi ES \& Volbekas V 1980 Inhibition by dopamine of oxytocin release from isolated posterior lobe of the hypophysis of the rat; disinhibitory effect of $\beta$-endorphin/enkephalin. Neuroendocrinology 31 46-52.

Vizi ES, Hársing LG Jr, Gaál J, Zimányi I \& Gaál G 1985 Release and turnover of noradrenaline in isolated median eminence: lack of negative feedback modulation. Neuroscience 16 907-916.

Wang G \& Lemos JR 1993 Inhibition by ATP of $\mathrm{Ca}^{2+}$ current and $\mathrm{Ca}^{2+}$ activated $\mathrm{K}^{+}$channel in isolated neurohypophyseal terminal. Society for Neuroscience Abstracts 191261.

Windscheif U 1996 Purinoceptors: from history to recent progress. A review. Journal of Pharmacology 48 993-1101.

Zimmermann H 1996 Biochemistry, localization and functional roles of ecto-nucleotidases in the nervous system. Progress in Neurobiology 49 589-618.

Received 22 June 1998

Accepted 13 October 1998 